\title{
Time Course and Diagnostic Utility of Nfl, Tau, GFAP, and UCH-L1 in Subacute and Chronic TBI
}

Neurology ${ }^{\circledR}$ 2021;96:593. doi:10.1212/WNL.0000000000011717

The authors of the article "Time Course and Diagnostic Utility of Nfl, Tau, GFAP, and UCHL1 in Subacute and Chronic TBI," ${ }^{1}$ revised the paper to acknowledge and cite duplication of analyses and figures in a companion paper. ${ }^{2}$ They made changes throughout the paper acknowledging that some of the figures and analyses are reproduced from the companion paper for ease of comparison. They also cite the companion paper in several places to ensure that the reader knows which of the analyses and figures are also contained in the companion paper. These changes have occurred in the Introduction, Methods, Results, Discussion, figure legends, tables, and supplementary material, and the online version of the article was updated on March 22. All changes are identified in the Highlighted Changes supplement linked from the updated version.

\section{References}

1. Shahim P, Politis A, van der Merwe A, et al. Time course and diagnostic utility of NfL, tau, GFAP, and UCH-L1 in subacute and chronic TBI. Neurology 2020;95:e623-e636.

2. Shahim P, Politis A, van der Merwe A, et al. Neurofilament light as a biomarker in traumatic brain injury. Neurology 2020;95:e610-e622.

\section{CORRECTION}

\section{Neurofilament Light as a Biomarker in Traumatic Brain Injury Neurology ${ }^{\circledR}$ 2021;96:593. doi:10.1212/WNL.0000000000011716}

In the article "Neurofilament Light as a Biomarker in Traumatic Brain Injury," by P. Shahim et al., ${ }^{1}$ some of the data regarding the cohort of Swedish athletes that are available in the paper's Supplementary Appendix should have been expanded upon and placed in the text of the main paper. As cited in the Supplementary Appendix, 45 of the cases reported in figures 2, B and C were previously included in the $2018 \mathrm{P}$. Shahim et al. ${ }^{2}$ article "Neurofilament light and tau as blood biomarkers for sports-related concussion," published in Neurology. These cases include all the preseason patients $(\mathrm{n}=28)$, and 17 of the 45 individuals in acute concussion $(\mathrm{AC})$ cohort. While some of the cases are the same, with the exception of the 17 individuals in the AC cohort, the data reported in the figures is novel and represents the results of separate lab analyses, using an updated in-house assay in 2019. Readers interested in knowing more about our Swedish cohort may refer to the 4 papers cited in the manuscript and Supplementary Appendix, as well as:

- Shahim P, Tegner Y, Marklund N, et al. Astroglial activation and amyloid metabolism in human repetitive concussion. Neurology 2017 Mar 10. doi: 10.1212/WNL. 0000000000003816.

- Siman R, Shahim P, Tegner Y, Blennow K, Zetterberg H, Smith DH. Serum SNTF Increases in Concussed Professional Ice Hockey Players and Relates to the Severity of Postconcussion Symptoms. J Neurotrauma Sep 1 2015;32(17):1294-1300.

- Shahim P, Linemann T, Inekci D, et al. Serum tau fragments predict return to play in concussed professional ice hockey players. J Neurotrauma Jan 262015.

- Shahim P, Tegner Y, Wilson DH, et al. Blood biomarkers for brain injury in concussed professional ice hockey players. JAMA Neurology Jun 2014;71(6):684-692.

\section{References}

1. Shahim P, Politis A, van der Merwe A, et al. Neurofilament light as a biomarker in traumatic brain injury. Neurology 2020;95:e610-e622.

2. Shahim P, Tegner Y, Marklund N, Blennow K, Zetterberg H. Neurofilament light and tau as blood biomarkers for sports-related concussion. Neurology 2018;90:e1780-e1788. 


\section{Neurology}

\section{Neurofilament Light as a Biomarker in Traumatic Brain Injury \\ Neurology 2021;96;593 \\ DOI 10.1212/WNL.0000000000011716}

This information is current as of March 22, 2021

\section{Updated Information \&} Services

References

Permissions \& Licensing

Reprints including high resolution figures, can be found at: http://n.neurology.org/content/96/12/593.2.full

This article cites 2 articles, 2 of which you can access for free at: http://n.neurology.org/content/96/12/593.2.full\#ref-list-1

Information about reproducing this article in parts (figures,tables) or in its entirety can be found online at:

http://www.neurology.org/about/about_the_journal\#permissions

Information about ordering reprints can be found online:

http://n.neurology.org/subscribers/advertise

Neurology ${ }^{\circledR}$ is the official journal of the American Academy of Neurology. Published continuously since 1951, it is now a weekly with 48 issues per year. Copyright (C 2021 American Academy of Neurology. All rights reserved. Print ISSN: 0028-3878. Online ISSN: 1526-632X.

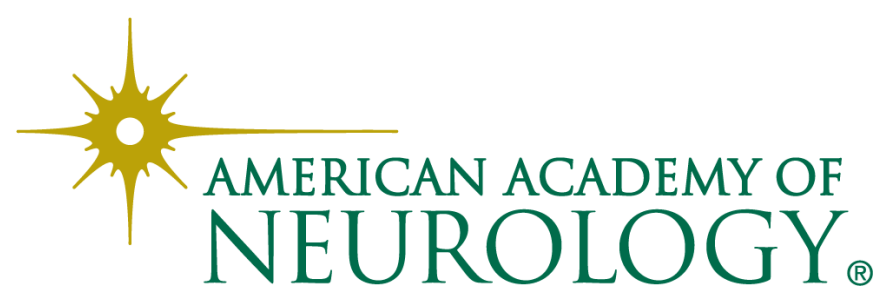

